\title{
The genetics of phaeochromocytoma: using clinical features to guide genetic testing
}

\author{
Mariam Jafri ${ }^{1,2}$ and Eamonn R Maher ${ }^{1,3}$ \\ ${ }^{1}$ Centre for Rare Diseases and Personalised Medicine, The Medical School, Institute of Biomedical Research West, University of Birmingham, Edgbaston, \\ Birmingham B15 2TT, UK, ${ }^{2}$ Department of Oncology, University Hospital Birmingham Foundation Trust, Edgbaston, Birmingham B15 2WB, UK and \\ ${ }^{3}$ West Midlands Region Genetics Service, Birmingham Women's Hospital, Edgbaston, Birmingham B15 2TG, UK \\ (Correspondence should be addressed to E R Maher at Centre for Rare Diseases and Personalised Medicine; Email: e.rmaher@bham.ac.uk)
}

\begin{abstract}
Phaeochromocytoma is a rare, usually benign, tumour predominantly managed by endocrinologists. Over the last decade, major advances have been made in understanding the molecular genetic basis of adrenal and extra-adrenal phaeochromocytoma (also referred to as adrenal phaeochromocytoma (aPCA) and extra-adrenal functional paraganglioma (eFPGL)). In contrast to the previously held belief that only $10 \%$ of cases had a genetic component, currently about one-third of all aPCA/eFPGL cases are thought to be attributable to germline mutations in at least nine genes (NF1, RET, SDHA, SDHB, SDHC, SDHD, TMEM127, MAX and VHL). Recognition of inherited cases of aPCA/eFPGL is critical for optimal patient management. Thus, the identification of a germline mutation can predict risks of malignancy, recurrent disease, associated non-chromaffin tumours and risks to other family members. Mutation carriers should be offered specific surveillance programmes (according to the relevant gene). In this review, we will describe the genetics of aPCA/eFPGL and strategies for genetic testing.
\end{abstract}

European Journal of Endocrinology 166 151-158

\section{Background}

Adrenal and extra-adrenal phaeochromocytoma (aPCA and extra-adrenal functional paraganglioma (eFPGL) respectively) has an incidence of $2-8$ cases per million per year. The nomenclature of these tumours can be confusing. The World Health Organization tumour classification defines phaeochromocytoma as chromaffin tumours arising from the adrenal medulla, and extra-adrenal tumours as paraganglioma. However, in the published literature the term paraganglioma may be used to refer to tumours derived from sympathetic nervous system or parasympathetic tissue. (Sympathetic tissue is located within the adrenal medulla, prevertebral, paravertebral, thoracoabdominal and pelvic paraganglia or in the reproductive organs, prostate, bladder, liver and organ of Zuckerkandl. Parasympathetic paraganglia are located in the vicinity of the major arteries and nerves, e.g. carotid body, jugular, vagal, tympanic, pulmonary and aortic paraganglioma.) In this review, we refer to aPCA/eFPGL to cover both chromaffin tumours that arise from the adrenal medulla (aPCA) and those functional extra-adrenal tumours derived from sympathetic ganglia (eFPGL). aPCA/eFPGL are usually secretary and typically present with features of catecholamine excess. In contrast, paragangliomas arising from the parasympathetic nervous system (usually within the head and neck and herein referred to as head and neck parasympathetic paraganglioma (HNPGL)) are predominantly endocrinologically inactive.

About $10 \%$ of aPCA/eFPGL patients have a family history of phaeochromocytoma and up to $25 \%$ of apparently sporadic cases with no family history will harbour a germline mutation in an inherited aPCA/eFPGL gene (1). To date, nine genes have been described to be associated with a predisposition to the development of aPCA/eFPGL and/or HNPGL (see Table 1). Although clues to inherited syndromic causes of aPCA/eFPGL may be provided by a previous history or family history of relevant tumour (see Table 1), many aPCA/eFPGL genes are associated with incomplete penetrance and/or variable expression (e.g. some VHL gene mutations may only be associated with aPCA/eFPGL). In addition to a positive family history of aPCA/eFPGL or evidence of a specific syndrome, the presence of multiple primary tumours is an indicator of genetic predisposition. In sporadic cases with a single tumour, early age at diagnosis, malignancy or extraadrenal location are all risk factors for the presence of a 
Table 1 The common phenotypic characteristics of the nine genes associated with the development of aPCA and eFPGL (see text for further details).

\begin{tabular}{|c|c|}
\hline Gene & Clinical phenotype \\
\hline$V H L$ & $\begin{array}{l}\text { von Hippel-Lindau disease - autosomal dominantly inherited predisposition to: aPCA/eFPGL, retinal and cerebellar } \\
\text { haemangioblastomas, clear renal cell carcinoma, non-secretory pancreatic neuroendocrine tumours, endolymphatic } \\
\text { tumours and visceral cysts (renal, pancreatic and epididymal). Rarely HNPGL. Epididymal cystadenomas }\end{array}$ \\
\hline RET & $\begin{array}{l}\text { Multiple endocrine neoplasia type } 2 \text { (MEN2) - autosomal dominantly inherited predisposition to medullary thyroid } \\
\text { carcinoma and aPCA. MEN2A is characterised by medullary thyroid carcinoma, aPCA and primary hyperparathyr- } \\
\text { oidism. MEN2B is characterised by medullary thyroid carcinoma and aPCA and developmental anomalies (marfanoid } \\
\text { habitus, mucosal neuromas, etc.). Phaeochromocytomas in MEN2 are characteristically adrenal and benign }\end{array}$ \\
\hline NF1 & $\begin{array}{l}\text { Neurofibromatosis type } 1 \text { (von Recklinghausen disease) autosomal dominantly inherited predisposition to } \\
\text { aPCA/eFPGL, peripheral nervous system tumours (cutaneous, nodular and plexiform neurofibromas), intestinal } \\
\text { tumours, gastrointestinal stromal cell tumours, malignant gliomas and juvenile chromic leukaemias. Relatively late } \\
\text { (compared with VHL disease and SDHB mutations) mean age of diagnosis ( } 41 \text { years) }\end{array}$ \\
\hline$S D H A$ & $\begin{array}{l}\text { Autosomal dominantly inherited predisposition to aPCA, eFPGL, HNPGL (though infrequent cause of these tumours) } \\
\text { (autosomal recessively inherited juvenile encephalopathy or neonatal cardiomyopathy) }\end{array}$ \\
\hline$S D H B$ & $\begin{array}{l}\text { Autosomal dominantly inherited predisposition to aPCA, eFPGL, HNPGL and renal cell carcinoma. High frequency of } \\
\text { extra-adrenal phaeochromocytoma and malignancy }\end{array}$ \\
\hline$S D H C$ & Autosomal dominantly inherited predisposition to HNPGL and, less frequently, aPCA and eFPGL \\
\hline$S D H D$ & $\begin{array}{l}\text { Autosomal dominantly inherited predisposition to parasympathetic HNPGL and aPCA and eFPGL. Tumours generally } \\
\text { only develop in individuals who have inherited the mutation from their father (i.e. parent-of-origin effects on disease } \\
\text { phenotype) }\end{array}$ \\
\hline TMEM127 & $\begin{array}{l}\text { Autosomal dominantly inherited predisposition to aPCA, eFPGL and HNPGL. Relatively late mean age of diagnosis } \\
\text { (compared with VHL disease and SDHB mutations) }\end{array}$ \\
\hline MAX & $\begin{array}{l}\text { Autosomal dominant inheritance with parent-of-origin effects (see text). Increased incidence of bilateral and malignan } \\
\text { phaeochromocytoma }\end{array}$ \\
\hline
\end{tabular}

aPCA, adrenal phaeochromocytoma; eFPGL, extra-adrenal functioning sympathetic paraganglioma; HNPGL, head and neck parasympathetic paraganglioma.

germline mutation (though the relevance of these risk factors varies for different genes) but there is no absolute cut off for mutation-positive cases (i.e. a patient with a later onset aPCA will have a low risk of harbouring a detectable mutation but the possibility cannot be completely excluded on clinical grounds).

\section{Clinical and molecular genetic features of specific phaeochromocytoma predisposing genes}

\section{VHL}

von Hippel-Lindau (VHL) disease is an autosomal dominant familial cancer syndrome with variable expression and age-dependent penetrance $(>90 \%$ by the age of 60 years) $(2,3)$. Germline VHL mutations are most commonly associated with retinal angioma, haemangioblastoma and clear cell renal cell carcinoma (average lifetime risk $>70 \%$ by the age of 60 years) (2). In addition to aPCA/eFPGL, non-secreting pancreatic neuroectodermal tumours occur in $\sim 10 \%$ of patients (4). Rarely, HNPGL may occur $(<1 \%)$ (5). Though renal, pancreatic and epididymal cysts are frequent (and may provide useful clues to the underlying diagnosis) they rarely cause morbidity. Interestingly, the risk of individual tumours can vary according to the germline VHL mutation. Although aPCA/eFPGL occur in $15-20 \%$ of individuals with VHL, the most common VHL mutations (deletions, truncating and splice-site mutations) are associated with a low risk of
aPCA/eFPGL, whereas missense mutations that are predicted not to impair the stability of the VHL protein have a high risk of aPCA/eFPGL. However, the risk of other tumours is variable (e.g. risk of RCC is low in type 2A VHL disease whereas type 2C VHL disease is only associated with aPCA/eFPGL) (3, 6, 7). Early detection and treatment of retinal angiomas and renal tumours reduces morbidity and mortality thus the detection of a germline VHL mutation as the cause of aPCA/eFPGL can profoundly alter the management of the patient (e.g. initiation of VHL disease tumour surveillance protocols) and their family. aPCA/eFPGL in VHL disease is characterised by a younger age at diagnosis (mean 28 years) and increased frequency of bilateral or multiple tumours although the risks of malignancy are not elevated (4). As many VHL-associated aPCA/eFPGL are detected during routine imaging surveillance, they are more frequently asymptomatic at diagnosis than sporadic aPCA/eFPGL.

\section{RET}

Germline activating mutations in the RET protooncogene cause multiple endocrine neoplasia type 2 (MEN2) and inactivating mutations cause Hirschsprung disease (8). Interestingly, a case of familial phaeochromocytoma described in 1886 was shown to result from a germline RET mutation 121 years later (9). MEN2 is an autosomal dominantly inherited disorder and is divided into three clinical subtypes, two of which (MEN2A and MEN2B) are characterised by the development of medullary thyroid cancer (MTC) and 
aPCA (and hyperparathyroidism in MEN2A and a marfanoid habitus and mucosal neuromas in MEN2B). A number of genotype-phenotype correlations have been described in MEN2. Missense mutations in the intracellular tyrosine kinase domain (e.g. p.Met918Thr) that are associated with a strong transforming activity are associated with MEN2B (MTC and aPCA have an earlier age at onset in MEN2B than MEN2A), whereas missense mutations (e.g. p.Cys634Arg or p.Cys634Tyr) in the extracellular domain that cause abnormal dimerization (and autoactivation) of the mutant proteins have a less transforming activity and cause MEN2A (10-12). Individuals with MEN2A have about a $50 \%$ risk of developing aPCA but the mean age at diagnosis of MTC is earlier than that of aPCA $(\sim 40$ years) and so, compared with individuals with germline SDHB, SDHD or VHL mutations, individuals with MEN2 are less likely to present with sporadic non-syndromic phaeochromocytoma. Nevertheless, a germline RET mutation can be detected in about $5 \%$ of such cases (13). Individuals with MEN2A often develop aPCA (which may be synchronous or metachronous) but eFPGL and malignancy are rare (14).

\section{Neurofibromatosis 1 (von Recklinghausen disease)}

Neurofibromatosis 1 (NF1) has been associated with phaeochromocytoma since 1910. Cutaneous (localised and plexiform neurofibromas, neurofibrosarcoma) and internal tumours such as aPCA/eFPGL, central nervous system tumours (glioma, astrocytoma and optic gliomas), carcinoid and leukaemia may occur (15). Although NF1 is relatively common (incidence one in 3000 persons), the prevalence of aPCA/eFPGL in NF1 is low $(\sim 1 \%)$. Therefore, NF1 is not a common diagnosis in aPCA/eFPGL patients (16). The median age at diagnosis of aPCA/eFPGL in NF1 is relatively late $(\sim 41$ years) and so other features of the disease (e.g. cutaneous cafe-au-lait spots, axillary freckling, neurofibromas and Lisch nodules) are usually present (so making clinical diagnosis of NF1 straightforward) $(17,18)$. The NF1 gene is a large gene (57 exons) and NF1 is associated with a wide variety of, frequently de novo, inactivating mutations making genetic analysis difficult. Therefore, although molecular genetic analysis is becoming more available, it is usually not indicated for diagnosis because of the ease of clinical diagnosis $(16,19)$.

\section{The succinate dehydrogenase complex}

Succinate dehydrogenase (SDH) is a heterotetrameric enzyme comprising four subunits (A, B, C and D). An associated protein, SDHAF2, is a highly conserved cofactor of flavin adenine dinucleotide (FAD) that is implicated in flavination of SDHA and is essential for
SDH function. The SDH complex is attached to the inner mitochondrial wall by SDHC and SDHD. SDH has two key roles in cellular energy production: as part of the mitochondrial tricarboxylic acid cycle (catalysing the oxidative dehydrogenation of succinate coupled to the reduction of ubiquinone) and as the complex II component of the electron transport chain.

Loss-of-function mutations in the four SDH complex subunits and SDHAF2 have been demonstrated to cause HNPGL and/or aPCA/eFPGL, though the relative mutation frequency and associated tumour types varies between individual genes.

SDHD mutations were initially associated with HNPGL and subsequently with aPCA/eFPGL (20, 21). Although early studies suggested that SDHD mutations were more strongly associated with HNPGL than aPCA/eFPGL (22), a recent report suggests that this is mainly attributable to a very low risk of aPCA/eFPGL with a common SDHD missense mutation (p.Pro81Leu) (23). Multifocal tumours are more common with SDHD mutations (22). It should be noted that the tumour risk with SDHD mutations is for mutations that have been paternally inherited (maternally transmitted mutations have only very rarely been linked with disease and routine surveillance is not indicated in such cases) $(24,25)$. Mean age at diagnosis of phaeochromocytoma in patients with SDHD mutations is 35 years (23).

SDHB mutations are an important cause of HNPGL and aPCA/eFPGL $(13,23,24,26)$. In addition, SDHB mutations predispose to renal tumours and may present with familial renal cell carcinoma (RCC) (27). Important clinical features of SDHB aPCA/eFPGL are a high frequency of extra-adrenal location and malignancy ( $\sim 20 \%$ of mutation carriers will develop malignant disease and up to $50 \%$ of patients with a malignant eFPGL harbour a germline $S D H B$ mutation) $(22,23$, 28-31). Compared with all patients with $S D H$ mutations, the overall risk of HNPGL (e.g. carotid body tumours) is higher with SDHD mutations whereas the risk of aPCA/eFPGL is higher with SDHB mutations $(22,27)$. Initial reports had suggested a high clinical penetrance for SDHB mutations; however, as testing of apparently sporadic cases has become more widespread and asymptomatic relatives of mutation carriers undergo genetic testing, the observed penetrance of SDHB mutations has fallen (e.g. $25-40 \%$ in nonprobands) (32). In addition to renal tumours, SDHB mutations may possibly predispose to thyroid tumours (though the absolute risk is small) and SDHB and SDHC mutations have been found in $12 \%$ of individuals with gastrointestinal stromal tumours without PDGFRA receptor mutations $(33,34)$.

SDHC mutations may be present in $\sim 4 \%$ of HNPGL patients and though aPCA/eFPGL can occur it is rare (35-38). In the French Paraganglioma cohort, 14 of the 16 patients with SDHC mutations had HNPGL and two had a thoracic eFPGL (39). 
SDHA mutations were initially described in a biallelic state (homozygous or compound heterozygous) in children with an autosomal recessively inherited juvenile encephalopathy (Leigh syndrome) (40) and mutations in SDHA were initially thought to be absent from patients with HNPGL or aPCA/eFPGL. However, recent reports have described heterozygous germline SDHA mutations in a small subset of patients with HNPGL and aPCA/eFPGL $(41,42)$.

\section{TMEM127}

Following genetic linkage studies that mapped a novel locus for familial phaeochromocytoma to chromosome 2q11, germline mutations were identified in TMEM127 (43). The presence of loss-of-function mutations and allele loss TMEM127 phaeochromocytoma was consistent with the TMEM127 acting as a tumour suppressor gene. TMEM127 encodes a three spanner transmembrane protein that is highly conserved and, although the function of TMEM127 is not well defined, it has been linked to mTOR signalling (43). In an extensive cohort analysis of 990 individuals with phaeochromocytoma or HNPGL, the frequency of TMEM127 mutations was $\sim 2 \%$ (44). In contrast to $V H L$ and $S D H B$ mutations, patients with mutations in TMEM127 do not have an early age at diagnosis (median age of 41.5 years). Typically, patients have aPCAs (often bilateral) and malignancy is infrequent $(43,44)$. The role of genetic testing for TMEM127 mutations in clinical practice is not well defined as, though mutations are uncommon, they may present in patient groups that are frequently excluded from genetic testing (see later) (44). Furthermore, the recent description of HNPGL and eFPGL in association with TMEM127 mutations demonstrates how the phenotype associated with inherited phaeochromocytoma gene mutations can continue to evolve (45).

\section{MAX}

Recently, germline inactivating mutations in MAX were detected by exome sequencing (46). Loss of wild-type $M A X$ was also noted in tumour DNA and immunostaining revealed loss of MAX expression consistent with a tumour suppressor function. MAX is a key component of the MYC-MAX-MXD1 network that regulates cell proliferation and differentiation and there is crosstalk between this network and the mTOR pathway (to which TMEM127 has been linked (see above)). Interestingly, evidence was found that paternal transmission of the gene was necessary for tumour development (as with SDHD and SDHAF2). Most cases of MAX-associated phaeochromocytoma were bilateral, confirming the association between genetic abnormalities and multiple tumours. An association with malignancy was also found.

\section{Other genes}

Two apparently very rare causes of phaeochromocytoma are mutations in KIF1B and PHD2. Mutations in these genes have been described in only a few or single families, respectively (47-50), and neither gene is routinely analysed in clinical practice. Mutations in SDHAF2/SDH5 have been described in association with HNPGL but, to date, not with phaeochromocytoma $(51,52)$. The SDHAF2 gene maps to chromosome $11 \mathrm{q} 13$ and, as with SDHD (11q23), there are parentof-origin effects on expression such that tumour development only occurs after paternal inheritance $(51,52)$.

\section{The molecular pathophysiology of inherited phaeochromocytoma}

It is clear that many genes are implicated in the pathogenesis of inherited phaeochromocytoma. However, gene expression studies have highlighted potential shared mechanisms of pathophysiology. For example, aPCA/eFPGL associated with germline mutations in VHL, SDHD and SDHB are associated with activation of hypoxic gene response pathways, whereas tumours associated with NF1 and RET mutations do not show a hypoxic gene signature but do show dysregulation of genes implicated in adrenergic metabolism, protein synthesis and kinase signalling (53-55). It was estimated that about $30 \%$ of sporadic aPCA and eFPGL have a similar gene expression signature to VHL/SDHX tumours and the other $70 \%$ to NF1/RET (53). Interestingly, the differences in gene expression profiles can be correlated with the tendency of VHL and SDHX tumours to produced mainly noradrenaline, and RET/NF1 tumours to be adrenergic (56). Recently, Burnichon et al. (55) have demonstrated that the gene expression profiling can be used to identify which subset of sporadic tumours are likely to harbour somatic VHL or RET mutations and so provide a basis for potential personalised therapies.

\section{Genetic testing in phaeochromocytoma patients}

The identification of inherited phaeochromocytoma genes provided the opportunity to define the frequency of specific gene mutations in both familial cases and in apparently non-syndromic sporadic cases. Unexpectedly, mutation analysis of RET, SDHB, SDHD and VHL revealed mutations in up to $25 \%$ of sporadic cases suggesting that at least a third of patients with phaeochromocytoma had inherited disease (13). The implications of identifying a germline mutation are profound - not only may close relatives be at risk for familial disease but the proband is generally placed at 
increased risk of developing further phaeochromocytoma tumours and, depending on the specific gene mutation, there may be a risk of developing other tumour types (see Table 1). Although it has been suggested that all patients with phaeochromocytoma should be offered genetic testing, such a policy is (with conventional mutation detection methodologies) expensive (e.g. a recent estimate for testing $S D H B, S D H C, S D H D, V H L$ and RET was $\$ 4100$ (57)), and so more targeted screening has been advocated. Clinical features that influence the odds of detecting a mutation in an individual case will include whether there is: i) a personal or family history to indicate a syndromic cause (e.g. MTC, HNPGL and haemangioblastoma); ii) a positive family history for phaeochromocytoma; iii) multiple primary phaeochromocytomas; iv) malignancy; v) extra-adrenal location; and vi) age at diagnosis (generally inherited tumours occur at an earlier age than non-inherited). In the seminal study by Neumann et al. (13), 70\% of individuals with phaeochromocytoma aged $<10$ years had a detectable mutation (in SDHB, SDHD, RET or VHL) compared with $8 \%$ of those who presented after age 40 years.

If a targeted approach to mutation analysis is to be pursued then it is generally agreed that those with a personal or family history of a specific syndromic cause and, in apparently non-syndromic cases, those with a positive family history for phaeochromocytoma, or multiple or bilateral tumours, should be analysed. It is usual to test individual genes sequentially and the order of testing can be individualised according to the likelihood of a syndromic cause (e.g. RET if there is a family history/personal history of MTC, $S D H B / D$ if a HNPGL) or, in apparently non-syndromic cases with familial or multicentric phaeochromocytoma, the presence of extra-adrenal or malignant tumours would favour starting with SDHB analysis (but VHL if an aPCA). There are no generally agreed criteria regarding which patients with apparently non-syndromic sporadic phaeochromocytoma should be offered genetic testing for most frequently mutated genes (SDHB, SDHD, VHL and RET) (NF1 genetic testing is only indicated if there is clinical evidence of the disorder). Clearly, the more targeted mutation analysis is designed to be, the more cost-effective (in terms of expenditure per mutation detected) but less sensitive it will be. We suggest that all patients with malignant phaeochromocytoma should be offered testing for SDHB, VHL and SDHD mutations as about $40-50 \%$ of such patients will have a detectable mutation $(\sim 35,5$ and $1 \%$ respectively). For patients with sporadic nonsyndromic eFPGLs the mutation detection rate is also high and we would also suggest testing SDHB, VHL and SDHD in such cases. For patients with a single benign aPCA it is generally agreed that the age at diagnosis be used to prioritise testing - though the precise age cut off has varied between investigators. In the largest study yet reported, Erlic et al. (57) suggested that an age cut off at 45 years would appreciably reduce the costs of genetic testing at the expense of only missing a relatively small number of mutation-positive cases $(<5 \%)$ and so, when budgets for genetic testing are limited, it seems reasonable to restrict genetic testing (VHL, RET, SDHB then SDHD) to these younger cases (see Fig. 1). As testing for TMEM127 and MAX becomes more widely available then the indications for including testing for these genes will need to be incorporated into genetic testing protocols.

Within 5 years a number of scientific research and technological advances are likely to make it entirely feasible to evaluate all phaeochromocytoma patients for the risk of inherited disease. Immunohistochemical analysis has been used to identify tumours with loss of SDHB and SDHA expression that can then be prioritised for mutation analysis. Thus, in a series of 220 phaeochromocytomas, van Nederveen et al. (58) found a $100 \%$ sensitivity and $84 \%$ specificity for the association of SDHB immunohistochemistry and the presence of a detectable mutation. Likewise, SDHA immunohistochemistry was used to identify cases for SDHA mutation analysis (42). Such immunohistochemical information (and we note that aPCA/eFPGL

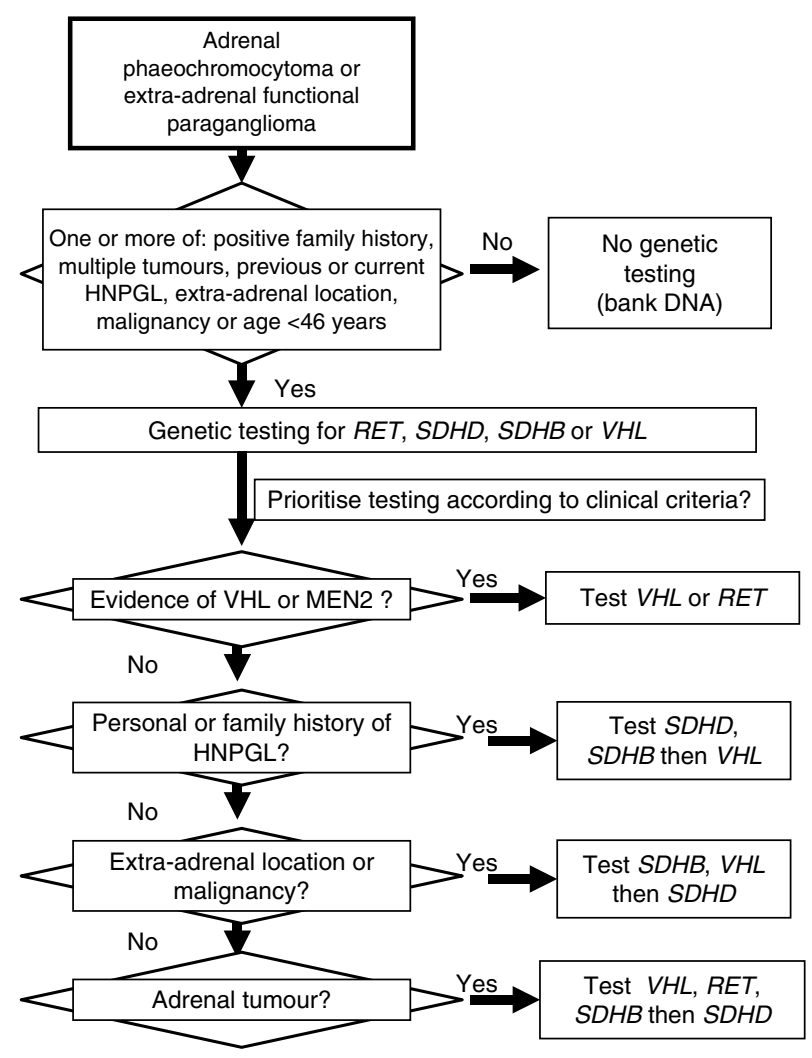

Figure 1 Example of targeted mutation analysis protocol for diagnostic testing of major genes (RET, SDHB, SDHD and $V H L)$ in patients presenting with adrenal phaeochromocytoma or eFPGL extra-adrenal functioning sympathetic paraganglioma and no evidence of a specific phaeochromocytoma syndrome (see text for details). 
associated with MAX mutations demonstrated loss of MAX expression (46)) might be combined with other biomarkers (e.g. evidence of tumour pseudohypoxia) to develop more sensitive and specific strategies for targeting mutation analysis $(53-55,58,59)$. In addition, advances in sequencing technologies (e.g. exon capture and targeted resequencing by second generation massively parallel sequencing) will reduce greatly the cost of genetic diagnosis and so allow comprehensive analysis for all (i.e. currently known and those yet to be identified) inherited phaeochromocytoma genes (60). Hence, clinicians should bear in mind that individuals who appear likely to have inherited disease but do not have a mutation in a currently known gene should have DNA banked to allow for future mutation analysis. However, it should be noted that whilst comprehensive genetic analysis will increase the identification of inherited predisposition cases, it will also identify rare genetic variants that might not be easily classified as a pathogenic mutation or a benign polymorphism and in such cases costly further investigations may be required. Thus, it is important to take into account all available clinical and laboratory information to advise on optimum management.

\section{Declaration of interest}

The authors declare that there is no conflict of interest that could be perceived as prejudicing the impartiality of the research reported.

\section{Funding}

This work was supported by the Birmingham Women's Hospital Springboard Fellowship Award to M Jafri.

\section{References}

1 Gimenez-Roqueplo AP, Lehnert H, Mannelli M, Neumann H, Opocher G, Maher ER \& Plouin PF \& European Network for the Study of Adrenal Tumours (ENS@T) Phaeochromocytoma Working Group. Phaeochromocytoma, new genes and screening strategies. Clinical Endocrinology 200665 699-705. (doi:10. $1111 / \mathrm{j} .1365-2265.2006 .02714 . x)$

2 Maher ER, Yates JR, Harries R, Benjamin C, Harris R, Moore AT \& Ferguson-Smith MA. Clinical features and natural history of von Hippel-Lindau disease. Quarterly Journal of Medicine 199077 1151-1163.

3 Ong KR, Woodward ER, Killick P, Lim C, Macdonald F \& Maher ER. Genotype-phenotype correlations in von Hippel-Lindau disease. Human Mutation 200728 143-149. (doi:10.1002/humu.20385)

4 Maher ER, Neumann HP \& Richard S. von Hippel-Lindau disease: a clinical and scientific review. European Journal of Human Genetics 201119 617-623. (doi:10.1038/ejhg.2010.175)

5 Boedeker CC, Erlic Z, Richard S, Kontny U, Gimenez-Roqueplo AP, Cascon A, Robledo M, de Campos JM, van Nederveen FH, de Krijger RR, Burnichon N, Gaal J, Walter MA, Reschke K, Wiech T, Weber J, Rückauer K, Plouin PF, Darrouzet V, Giraud S, Eng C \& Neumann HP. Head and neck paragangliomas in von HippelLindau disease and multiple endocrine neoplasia type 2. Journal of Clinical Endocrinology and Metabolism 200994 1938-1944. (doi:10.1210/jc.2009-0354)
6 Crossey PA, Richards FM, Foster K, Green JS, Prowse A, Latif F, Lerman MI, Zbar B, Affara NA, Ferguson-Smith MA \& Maher ER. Identification of intragenic mutations in the von Hippel-Lindau disease tumour suppressor gene and correlation with disease phenotype. Human Molecular Genetics 19943 1303-1308. (doi:10.1093/hmg/3.8.1303)

7 Woodward ER, Eng C, McMahon R, Voutilainen R, Affara NA, Ponder BA \& Maher ER. Genetic predisposition to phaeochromocytoma: analysis of candidate genes GDNF, RET and VHL. Human Molecular Genetics 19976 1051-1056. (doi:10.1093/hmg/6.7. 1051)

8 Moline J \& Eng C. Multiple endocrine neoplasia type 2: an overview. Genetics in Medicine 201113 755-764.

9 Neumann HP, Vortmeyer A, Schmidt D, Werner M, Erlic Z, Cascon A, Bausch B, Januszewicz A \& Eng C. Evidence of MEN-2 in the original description of classic pheochromocytoma. New England Journal of Medicine 2007357 1311-1315. (doi:10. 1056/NEJMoa071407)

10 Eng C, Clayton D, Schuffenecker I, Lenoir G, Coke G, Gagel RF, van Arnstel HK, Lips CJ, Nishisho I, Takai SI, Marsh DJ, Robinson BG, Frank-Raue K, Raue F, Xue F, Noll WW, Romei C, Pacini F, Fink M, Niederle B, Zedenius J, Nordenskjold M, Komminoth P, Hendy GN \& Mulligan LM. The relationship between specific RET protooncogene mutations and disease phenotype in multiple endocrine neoplasia type 2. International RET mutation consortium analysis. Journal of the American Medical Association 1996276 1575-1579.

11 Gujral TS, Singh VK, Jia Z \& Mulligan LM. Molecular mechanisms of RET receptor-mediated oncogenesis in multiple endocrine neoplasia 2B. Cancer Research 200666 10741-10749. (doi:10. 1158/0008-5472.CAN-06-3329)

12 Eng C. Common alleles of predisposition in endocrine neoplasia. Current Opinion in Genetics \& Development 201020 251-256. (doi:10.1016/j.gde.2010.02.004)

13 Neumann HP, Neumann HP, Bausch B, McWhinney SR, Bender BU, Gimm O, Franke G, Schipper J, Klisch J, Altehoefer C, Zerres K, Januszewicz A, Eng C, Smith WM, Munk R, Manz T, Glaesker S, Apel TW, Treier M, Reineke M, Walz MK, Hoang-Vu C, Brauckhoff M, Klein-Franke A, Klose P, Schmidt H, MaierWoelfle M, Peçzkowska M, Szmigielski C \& Eng C. Germ-line mutations in nonsyndromic pheochromocytoma. New England Journal of Medicine 2002346 1459-1466. (doi:10.1056/ NEJMoa020152)

14 Opocher G \& Schiavi F. Genetics of phaeochromocytomas and paragangliomas. Best Practice $\mathcal{E}$ Research. Clinical Endocrinology $\mathcal{E}$ Metabolism $20066943-956$.

15 Larizza L, Gervasini C, Natacci F \& Riva P. Developmental abnormalities and cancer predisposition in neurofibromatosis type 1. Current Molecular Medicine 20099 634-653. (doi:10. 2174/156652409788488801)

16 Bausch B, Koschker AC, Fassnacht M, Stoevesandt J, Hoffmann MM, Eng C, Allolio B \& Neumann HP. Comprehensive mutation scanning of NF1 in apparently sporadic cases of pheochromocytoma. Journal of Clinical Endocrinology and Metabolism 200691 3478-3481. (doi:10.1210/jc.2006-0780)

17 Jett K \& Friedman JM. Clinical and genetic aspects of neurofibromatosis 1. Genetics in Medicine 201012 1-11. (doi:10.1097/ GIM.0b013e3181bf15e3)

18 Lu-Emerson C \& Plotkin SR. The neurofibromatoses. Part 1: NF1. Reviews in Neurological Diseases 20096 E47-E53.

19 Bausch B, Borozdin W, Mautner VF, Hoffmann MM, Boehm D, Robledo M, Cascon A, Harenberg T, Schiavi F, Pawlu C, Peczkowska M, Letizia C, Calvieri S, Arnaldi G, KlingenbergNoftz RD, Reisch N, Fassina A, Brunaud L, Walter MA, Mannelli M, MacGregor G, Palazzo FF, Barontini M, Walz MK, Kremens B, Brabant G, Pfäffle R, Koschker AC, Lohoefner F, Mohaupt M, Gimm O, Jarzab B, McWhinney SR, Opocher G, Januszewicz A, Kohlhase J, Eng C \& Neumann HP \& EuropeanAmerican Phaeochromocytoma Registry Study Group. Germline NF1 mutational spectra and loss-of-heterozygosity analyses in 
patients with pheochromocytoma and neurofibromatosis type 1 . Journal of Clinical Endocrinology and Metabolism $2007 \mathbf{9 2}$ 2784-2792. (doi:10.1210/jc.2006-2833)

20 Baysal BE, Ferrell RE, Willett-Brozick JE, Lawrence EC, Myssiorek D, Bosch A, van der Mey A, Taschner PE, Rubinstein WS, Myers EN, Richard CW III, Cornelisse CJ, Devilee P \& Devlin B. Mutations in SDHD, a mitochondrial complex II gene, in hereditary paraganglioma. Science $2000 \mathbf{2 8 7}$ 848-851. (doi:10.1126/science.287.5454.848)

21 Astuti D, Douglas F, Lennard TW, Aligianis IA, Woodward ER, Evans DG, Eng C, Latif F \& Maher ER. Germline SDHD mutation in familial phaeochromocytoma. Lancet 2001a 357 1181-1182. (doi:10.1016/S0140-6736(00)04378-6)

22 Neumann HP, Pawlu C, Peczkowska M, Bausch B, McWhinney SR, Muresan M, Buchta M, Franke G, Klisch J, Bley TA, Hoegerle S, Boedeker CC, Opocher G, Schipper J, Januszewicz A \& Eng C \& European-American Paraganglioma Study Group. Distinct clinical features of paraganglioma syndromes associated with SDHB and SDHD gene mutations. Journal of the American Medical Association 2004292 943-951. (doi:10.1001/jama.292.8.943)

23 Ricketts CJ, Forman JR, Rattenberry E, Bradshaw N, Lalloo F, Izatt L, Cole TR, Armstrong R, Kumar VK, Morrison PJ, Atkinson AB, Douglas F, Ball SG, Cook J, Srirangalingam U, Killick P, Kirby G, Aylwin S, Woodward ER, Evans DG, Hodgson SV, Murday V, Chew SL, Connell JM, Blundell TL, Macdonald F \& Maher ER. Tumor risks and genotype-phenotype-proteotype analysis in 358 patients with germline mutations in SDHB and SDHD. Human Mutation 201031 41-51. (doi:10.1002/humu. 21136)

24 Pigny P, Vincent A, Cardot Bauters C, Bertrand M, de Montpreville VT, Crepin M, Pardet N \& Caron P. Paraganglioma after maternal transmission of succinate dehydrogenase gene mutation. Journal of Clinical Endocrinology and Metabolism 200893 1609-1615. (doi:10.1210/jc.2007-1989)

25 Neumann HP \& Erlic Z. Maternal transmission of symptomatic disease with SDHD mutation: fact or fiction. Journal of Clinical Endocrinology and Metabolism 200893 1573-1575. (doi:10. 1210/jc.2008-0569)

26 Astuti D, Latif F, Dallol A, Dahia PL, Douglas F, George E, Skoldberg F, Husebye ES, Eng C \& Maher ER. Gene mutations in the succinate dehydrogenase subunit SDHB cause susceptibility to familial pheochromocytoma and to familial paraganglioma. American Journal of Human Genetics 2001b 69 49-54. (doi:10. $1086 / 321282)$

27 Ricketts C, Woodward ER, Killick P, Morris MR, Astuti D, Latif F \& Maher ER. Germline SDHB mutations and familial renal cell carcinoma. Journal of the National Cancer Institute $2008 \mathbf{1 0 0}$ 1260-1262. (doi:10.1093/jnci/djn254)

28 Gimenez-Roqueplo AP, Favier J, Rustin P, Rieubland C, Crespin M, Nau V, Khau Van Kien P, Corvol P, Plouin PF \& Jeunemaitre X \& COMETE Network. Mutations in the SDHB gene are associated with extra-adrenal and/or malignant phaeochromocytomas. Cancer Research 200363 5615-5621.

29 Amar L, Bertherat J, Baudin E, Ajzenberg C, Bressac-de Paillerets B, Chabre O, Chamontin B, Delemer B, Giraud S, Murat A, Niccoli-Sire P, Richard S, Rohmer V, Sadoul JL, Strompf L, Schlumberger M, Bertagna X, Plouin PF, Jeunemaitre X \& Gimenez-Roqueplo AP. Genetic testing in pheochromocytoma or functional paraganglioma. Journal of Clinical Oncology 200523 8812-8818. (doi:10.1200/JCO.2005.03.1484)

30 Brouwers FM, Eisenhofer G, Tao JJ, Kant JA, Adams KT, Linehan WM \& Pacak K. High frequency of SDHB germline mutations in patients with malignant catecholamine-producing paragangliomas: implications for genetic testing. Journal of Clinical Endocrinology and Metabolism 200691 4505-4509. (doi:10. 1210/jc.2006-0423)

31 Amar L, Baudin E, Burnichon N, Peyrard S, Silvera S, Bertherat J, Bertagna X, Schlumberger M, Jeunemaitre X, GimenezRoqueplo AP \& Plouin PF. Succinate dehydrogenase B gene mutations predict survival in patients with malignant pheochromocytomas or paragangliomas. Journal of Clinical Endocrinology and Metabolism 200792 3822-3828. (doi:10. 1210/jc.2007-0709)

32 Schiavi F, Milne RL, Anda E, Blay P, Castellano M, Opocher G, Robledo M \& Cascón A. Are we overestimating the penetrance of mutations in SDHB? Human Mutation 201031 761-762. (doi:10. 1002/humu.21269)

33 Pasini B, McWhinney SR, Bei T, Matyakhina L, Stergiopoulos S, Muchow M, Boikos SA, Ferrando B, Pacak K, Assie G, Baudin E, Chompret A, Ellison JW, Briere JJ, Rustin P, Gimenez-Roqueplo AP, Eng C, Carney JA \& Stratakis CA. Clinical and molecular genetics of patients with the Carney-Stratakis syndrome and germline mutations of the genes coding for the succinate dehydrogenase subunits SDHB, SDHC, and SDHD. European Journal of Human Genetics 200816 79-88. (doi:10.1038/sj.ejhg.5201904)

34 Janeway KA, Kim SY, Lodish M, Nosé V, Rustin P, Gaal J, Dahia PL, Liegl B, Ball ER, Raygada M, Lai AH, Kelly L, Hornick JL, O'Sullivan M, de Krijger RR, Dinjens WN, Demetri GD, Antonescu CR, Fletcher JA, Helman L \& Stratakis CA. Defects in succinate dehydrogenase in gastrointestinal stromal tumors lacking KIT and PDGFRA mutations. PNAS $2011 \mathbf{1 0 8}$ 314-318. (doi:10.1073/pnas.1009199108)

35 Mannelli J, Ercolino T, Giache V, Simi L, Cirami C \& Paranti G. Genetic screening for phaeochromocytoma: should SDHC gene analysis be included? Journal of Medical Genetics $2007 \mathbf{4 4}$ 586-587. (doi:10.1136/jmg.2007.051045)

36 Peczkowska M, Cascon A, Prejbisz A, Kubaszek A, Cwiskla BJ, Furmanek M, Erlic Z \& Eng C. Extra-adrenal and adrenal phaeochromocytomas associated with a germline SDHC mutation. Nature Clinical Practice. Endocrinology \& Metabolism 20084 111-115. (doi:10.1038/ncpendmet0726)

37 Schiavi F, Boedeker CC, Bausch B, Peçzkowska M, Gomez CF, Strassburg T, Pawlu C, Buchta M, Salzmann M, Hoffmann MM, Berlis A, Brink I, Cybulla M, Muresan M, Walter MA, Forrer F, Välimäki M, Kawecki A, Szutkowski Z, Schipper J, Walz MK, Pigny P, Bauters C, Willet-Brozick JE, Baysal BE, Januszewicz A, Eng C, Opocher G \& Neumann HP \& European-American Paraganglioma Study Group. Predictors and prevalence of paraganglioma syndrome associated with mutations of the SDHC gene. Journal of the American Medical Association 2005 294 2057-2063. (doi:10.1001/jama.294.16.2057)

38 Timmers HJ, Gimenez-Roqueplo AP, Mannelli M \& Pacak K. Clinical aspects of SDHx-related pheochromocytoma and paraganglioma. Endocrine-Related Cancer 200916 391-400. (doi:10. 1677/ERC-08-0284)

39 Burnichon N, Rohmer V, Amar L, Herman P, Leboulleux S, Darrouzet V, Niccoli P, Gaillard D, Chabrier G, Chabolle F, Coupier I, Thieblot P, Lecomte P, Bertherat J, Wion-Barbot N, Murat A, Venisse A, Plouin PF, Jeunemaitre X \& GimenezRoqueplo AP \& PGLNET network. The succinate dehydrogenase genetic testing in a large prospective series of patients with paragangliomas. Journal of Clinical Endocrinology and Metabolism 200994 2817-2827. (doi:10.1210/jc.2008-2504)

40 Bourgeron T, Rustin P, Chretien D, Birch-Machin M, Bourgeois M, Viegas-Pequignot E, Munnich A \& Rotig A. Mutation of a nuclear succinate dehydrogenase gene results in mitochondrial respiratory chain deficiency. Nature Genetics 199511 144-149. (doi:10. 1038/ng1095-144)

41 Burnichon N, Brière JJ, Libé R, Vescovo L, Rivière J, Tissier F, Jouanno E, Jeunemaitre X, Bénit P, Tzagoloff A, Rustin P, Bertherat J, Favier J \& Gimenez-Roqueplo AP. SDHA is a tumor suppressor gene causing paraganglioma. Human Molecular Genetics 201019 3011-3020. (doi:10.1093/hmg/ddq206)

42 Korpershoek E, Favier J, Gaal J, Burnichon N, van Gessel B, Oudijk L, Badoual C, Gadessaud N, Venisse A, Bayley JP, van Dooren MF, de Herder WW, Tissier F, Plouin PF, van Nederveen FH, Dinjens WN, Gimenez-Roqueplo AP \& de Krijger RR. SDHA immunohistochemistry detects germline SDHA gene mutations in apparently sporadic paragangliomas and pheochromocytomas. Journal of Clinical Endocrinology and Metabolism 201196 E1472-E1476. (doi:10.1210/jc.2011-1043) 
43 Qin Y, Yao L, King EE, Buddavarapu K, Lenci RE, Chocron ES, Lechleiter JD, Sass M, Aronin N, Schiavi F, Boaretto F, Opocher G, Toledo RA, Toledo SP, Stiles C, Aguiar RC \& Dahia PL. Germline mutations in TMEM127 confer susceptibility to pheochromocytoma. Nature Genetics 201042 229-233. (doi:10.1038/ng.533)

44 Yao L, Schiavi F, Cascon A, Qin Y, Inglada-Pérez L, King EE, Toledo RA, Ercolino T, Rapizzi E, Ricketts CJ, Mori L, Giacchè M, Mendola A, Taschin E, Boaretto F, Loli P, Iacobone M, Rossi GP, Biondi B, Lima-Junior JV, Kater CE, Bex M, Vikkula M, Grossman AB, Gruber SB, Barontini M, Persu A, Castellano M, Toledo SP, Maher ER, Mannelli M, Opocher G, Robledo M \& Dahia PL. Spectrum and prevalence of FP/TMEM127 gene mutations in pheochromocytomas and paragangliomas. Journal of the American Medical Association $2010 \quad \mathbf{3 0 4}$ 2611-2619. (doi:10.1001/jama.2010.1830)

45 Neumann HP, Sullivan M, Winter A, Malinoc A, Hoffmann MM, Boedeker CC, Bertz H, Walz MK, Moeller LC, Schmid KW \& Eng C. Germline mutations of the TMEM127 gene in patients with paraganglioma of head and neck and extraadrenal abdominal sites. Journal of Clinical Endocrinology and Metabolism 201196 E1279-E1282. (doi:10.1210/jc.2011-0114)

46 Comino-Méndez I, Gracia-Aznárez FJ, Schiavi F, Landa I, LeandroGarcía LJ, Letón R, Honrado E, Ramos-Medina R, Caronia D, Pita G, Gómez-Graña A, de Cubas AA, Inglada-Pérez L, Maliszewska A, Taschin E, Bobisse S, Pica G, Loli P, HernándezLavado R, Díaz JA, Gómez-Morales M, González-Neira A, Roncador G, Rodríguez-Antona C, Benítez J, Mannelli M, Opocher G, Robledo M \& Cascón A. Exome sequencing identifies MAX mutations as a cause of hereditary pheochromocytoma. Nature Genetics 201143 663-667. (doi:10.1038/ng.861)

47 Munirajan AK, Ando K, Mukai A, Takahashi M, Suenaga Y, Ohira M, Koda T, Hirota T, Ozaki T \& Nakagawara A. KIF1Bbeta functions as a haploinsufficient tumor suppressor gene mapped to chromosome 1p36.2 by inducing apoptotic cell death. Journal of Biological Chemistry 2008283 24426-24434. (doi:10.1074/jbc. M802316200)

48 Ladroue C, Carcenac R, Leporrier M, Gad S, Le Helloe C, GalateauSalle F, Feunteun J, Pouysségur J, Richard S \& Gardie B. PHD2 mutation and congenital erythrocytosis with paraganglioma. New England Journal of Medicine 2008359 2685-2692. (doi:10.1056/ NEJMoa0806277)

49 Yeh IT, Lenci RE, Qin Y, Buddavarapu K, Ligon AH, Leteurtre E, Do Cao C, Cardot-Bauters C, Pigny P \& Dahia PL. A germline mutation of the KIF1B beta gene on 1 p36 in a family with neural and nonneural tumors. Human Genetics $2008 \mathbf{1 2 4} 279-285$. (doi:10.1007/s00439-008-0553-1)

50 Astuti D, Ricketts CJ, Chowdhury R, McDonough MA, Gentle D, Kirby G, Schlisio S, Kenchappa RS, Carter BD, Kaelin WG Jr, Ratcliffe PJ, Schofield CJ, Latif F \& Maher ER. Mutation analysis of HIF prolyl hydroxylases (PHD/EGLN) in individuals with features of phaeochromocytoma and renal cell carcinoma susceptibility. Endocrine-Related Cancer 201018 73-83. (doi:10.1677/ERC-100113)

51 Hao HX, Khalimonchuk O, Schraders M, Dephoure N, Bayley JP, Kunst H, Devilee P, Cremers CW, Schiffman JD, Bentz BG, Gygi SP, Winge DR, Kremer H \& Rutter J. SDH5, a gene required for flavination of succinate dehydrogenase, is mutated in paraganglioma. Science 2009325 1139-1142. (doi:10.1126/science. 1175689)

52 Bayley JP, Kunst HP, Cascon A, Sampietro ML, Gaal J, Korpershoek E, Hinojar-Gutierrez A, Timmers HJ, Hoefsloot LH, Hermsen MA, Suárez C, Hussain AK, Vriends AH, Hes FJ, Jansen JC, Tops CM, Corssmit EP, de Knijff P, Lenders JW, Cremers CW, Devilee P, Dinjens WN, de Krijger RR \& Robledo M. SDHAF2 mutations in familial and sporadic paraganglioma and phaeochromocytoma. Lancet Oncology $2010 \quad 11366-372$. (doi:10.1016/S1470-2045(10)70007-3)
53 Dahia PL, Ross KN, Wright ME, Hayashida CY, Santagata S, Barontini M, Kung AL, Sanso G, Powers JF, Tischler AS, Hodin R, Heitritter S, Moore F, Dluhy R, Sosa JA, Ocal IT, Benn DE, Marsh DJ, Robinson BG, Schneider K, Garber J, Arum SM, Korbonits M, Grossman A, Pigny P, Toledo SP, Nosé V, Li C \& Stiles CD. A HIF1alpha regulatory loop links hypoxia and mitochondrial signals in pheochromocytomas. PLoS Genetics 20051 72-80. (doi:10.1371/journal.pgen.0010008)

54 Pollard PJ, El-Bahrawy M, Poulsom R, Elia G, Killick P, Kelly G, Hunt T, Jeffery R, Seedhar P, Barwell J, Latif F, Gleeson MJ, Hodgson SV, Stamp GW, Tomlinson IP \& Maher ER. Expression of HIF-1alpha, HIF-2alpha (EPAS1), and their target genes in paraganglioma and pheochromocytoma with VHL and SDH mutations. Journal of Clinical Endocrinology and Metabolism 2006 91 4593-4598. (doi:10.1210/jc.2006-0920)

55 Burnichon N, Vescovo L, Amar L, Libé R, de Reynies A, Venisse A, Jouanno E, Laurendeau I, Parfait B, Bertherat J, Plouin PF, Jeunemaitre X, Favier J \& Gimenez-Roqueplo AP. Integrative genomic analysis reveals somatic mutations in pheochromocytoma and paraganglioma. Human Molecular Genetics 2011.

56 Huynhh TT, Pack K, Wang DL, Linehan WM, Goldsterin DS, Eikahloun AG, Munson PJ \& Eisenhoser G. Transcriptional regulation of phenylethanolamine $n$-methyltransferases in phaeochromocytoma from patients with von Hippel-Lindau syndrome and MEN type 2. Annals of the New York Academy of Sciences 2006 1073 241-252. (doi:10.1196/annals.1353.026)

57 Erlic Z, Rybicki L, Peczkowska M, Golcher H, Kann PH, Brauckhoff M, Müssig K, Muresan M, Schäffler A, Reisch N, Schott M, Fassnacht M, Opocher G, Klose S, Fottner C, Forrer F, Plöckinger U, Petersenn S, Zabolotny D, Kollukch O, Yaremchuk S, Januszewicz A, Walz MK, Eng C \& Neumann HP. Clinical predictors and algorithm for the genetic diagnosis of pheochromocytoma patients. Clinical Cancer Research 200915 6378-6385. (doi:10. 1158/1078-0432.CCR-09-1237)

58 van Nederveen FH, Gaal J, Favier J, Korpershoek E, Oldenburg RA, de Bruyn EM, Sleddens HF, Derkx P, Rivière J, Dannenberg H, Petri BJ, Komminoth P, Pacak K, Hop WC, Pollard PJ, Mannelli M, Bayley JP, Perren A, Niemann S, Verhofstad AA, de Bruïne AP, Maher ER, Tissier F, Méatchi T, Badoual C, Bertherat J, Amar L, Alataki D, Van Marck E, Ferrau F, François J, de Herder WW, Peeters MP, van Linge A, Lenders JW, Gimenez-Roqueplo AP, de Krijger RR \& Dinjens WN. An immunohistochemical procedure to detect patients with paraganglioma and phaeochromocytoma with germline SDHB, SDHC, or SDHD gene mutations: retrospective and prospective analysis. Lancet Oncology $2009 \mathbf{8}$ 764-771. (doi:10.1016/S1470-2045(09)70164-0)

59 López-Jiménez E, Gómez-López G, Leandro-García LJ, Muñoz I, Schiavi F, Montero-Conde C, de Cubas AA, Ramires R, Landa I, Leskelä S, Maliszewska A, Inglada-Pérez L, de la Vega L, Rodríguez-Antona C, Letón R, Bernal C, de Campos JM, DiezTascón C, Fraga MF, Boullosa C, Pisano DG, Opocher G, Robledo M \& Cascón A. Research resource: transcriptional profiling reveals different pseudohypoxic signatures in SDHB and VHL-related pheochromocytomas. Molecular Endocrinology $2010242382-$ 2391. (doi:10.1210/me.2010-0256)

60 Hoischen A, Gilissen C, Arts P, Wieskamp N, van der Vliet W, Vermeer S, Steehouwer M, de Vries P, Meijer R, Seiqueros J, Knoers NV, Buckley MF, Scheffer H \& Veltman JA. Massively parallel sequencing of ataxia genes after array-based enrichment. Human Mutation 2010 31 494-499. (doi:10.1002/humu.21221)

Received 6 June 2011

Revised version received 1 September 2011

Accepted 5 September 2011 